\title{
Tax Morale and Its Effect on Taxpayers' Compliance to Tax Policies of the Nigerian Government
}

\author{
Akan David Chucks, Odita Ogomrgbunam Anthony. \\ Accounting, Banking and Finance Department \\ Delta State University Asaba Campus Delta State-Nigeria \\ $\&$ \\ Odita Ogomegbunam Anthony \\ Accounting, Banking and Finance Department \\ Delta State University Asaba Campus Delta State-Nigeria
}

\begin{abstract}
Tax morale and its effect on taxpayers' compliance to the tax policies of the Nigerian government was investigated. The aim of this research is to bring to bare the reason for low tax compliance in Nigeria. Primary data via structured questionnaire was used. The data were regressed using statistical package for social sciences (SPSS16). The result showed that social norms, attitude towards government, tax evasion and tax avoidance have significant effect on tax morale. On the other hand, there is no significant effect of attitude towards legal system and traditional institutions on tax morale. We also established a significant positive effect of tax morale on tax compliance. The researcher therefore recommended that, tax payers should be educated to know their obligation as far as tax is concerned. The younger generation should also be educated on the need to pay tax correctly if the future of tax obedience is anything to go by. The Monarchs should also help in ensuring that their subjects obey the law of the land viz a viz tax compliance. Finally, tax payer's monies should be used for the right purpose.

Nigeria is governed by a Federal system and the government's fiscal power is based on a three-tier tax structure divided among the Federal, State, and Local governments, each of which has different tax jurisdictions. The Nigerian tax system is lopsided. The federal government controls all the major sources of revenue like import and excise duties, mining rents and royalties, petroleum profit tax and company income tax, value added tax among other revenue sources. State and local government taxes are minimal, hence, this limits their ability to raise independent revenue and so they depend solely on allocation from Federation Account.

The role of taxation in economic development is controversial. Plausibly, the concept of taxation has been a concern of global significance as it affects every economy irrespective of national differences Oboh et al (2012). Within the context of Africa, tax, a concept as old as mankind can be described as an amount, effort, contribution or service rendered either in kind (i.e. goat, cow, farm produce, clearing of grass etc.) or monetary value (i.e. cash) contributed into a common purse for the running of the society. According to Omotoso (2001), in his definition of the modern taxes, defined tax as a compulsory charge imposed by a public authority on the income of individuals and companies as stipulated by the government decrees, acts or cases laws irrespective of the exact amount of services rendered to the payer in return. Thus, taxes constitute the principal source of government revenue and the beauty of any government is for its citizen to voluntarily execute their tax obligations without much coercion and harassment.
\end{abstract}

\section{Statement Of Research Problem}

Low tax compliance is a matter of serious concern in many developing countries. This is because it limits the capacity of government to raise revenue for developmental purposes (Torgler, 2003). This implies that the higher the revenue, the more likely government will put in place developmental plans for the enhancement of the living standard of the people. This is because when people pay taxes more revenue accrues to the government. The major problem of this research therefore, is to determine the effect of tax morale on the taxpayer in compliance with tax policies of government as a useful avenue for revenue generation.

There are limits for a government to increase compliance using traditional policies such as audits and fines. Therefore, if the government can influence a norm, tax evasion can be reduced by policy activities.

Most researchers on tax compliance such as (Torgler, 2003), (McBarnet, 2003) and (Murphy and Harris, 2007). focused their attention on the Western World and some Asian countries. Socio-cultural factors are important components in the lives of a people and given the deep-rooted and pervasiveness of these in the Nigerian societies, there is a clear need for more empirical research on the factors involved. It is therefore, the focus of this study to subject tax compliance to empirical analysis in the Nigerian context. 


\section{Objectives Of The Study}

The general objective of this study is to determine the effect of Tax Morale on the taxpayer in compliance with tax policies of government in Nigeria. In doing so, it seeks to:

i Determine the extent of tax morale on the tax payer and its effect on tax compliance.

ii Ascertain the effect of trust in government on tax compliance.

iii Examine the effect of Nigerian Traditional Institution on tax morale of tax payers.

iv Determine the effect of cultural norms on the tax payers' morale.

$\mathrm{v}$ Ascertain the tax payer's confidence in the legal system on tax morale.

\section{Research Questions}

This study is an effort at understanding the effect of tax morale on tax compliance in the Nigerian context. Therefore, the study is hinged on the following questions;

$\mathrm{i}$ What is the effect of tax morale on taxpayer's compliance?

ii Will trust in government affect tax compliance?

iii To what extent has confidence in the legal system affect tax compliance?

iv What is the relationship between Traditional Institution and tax morale?

$\mathrm{v}$ To what extent has social norms affect tax morale?

\section{HYPOTHESES}

Hypotheses are assumptions on which a researcher bases his investigation and on the basis of which a confirmation of the assumed conditions are tested and validated. The hypothesis on which this research study is based are stated in null form as follows:

HYPOTHESES I

$\mathrm{H}_{0} ; \quad$ Tax Morale has no significant effect on tax payer compliance.

$\mathrm{H}_{\mathrm{I}}$ : $\quad$ Tax Morale has a significant effect on tax payer's compliance.

HYPOTHESES II

$\mathrm{H}_{0} ; \quad$ There is no significant relationship between trust in government and tax compliance.

$\mathrm{H}_{\mathrm{I}}: \quad$ There is a significant relationship between trust in government and tax compliance.

\section{HYPOTHESES III}

$\mathrm{H}_{0}$; There is no significant relationship between the Nigerian Traditional Institution and tax compliance.

$\mathrm{H}_{\mathrm{I}}$ : There is significant relationship between the Nigerian Traditional Institution and tax compliance.

\section{HYPOTHESES IV}

$\mathrm{H}_{0}$; There is no significant relationship between taxpayers cultural norms and the extent of their tax

compliance

$\mathrm{H}_{\mathrm{I}}$ : There is no significant relationship between taxpayers cultural norms and the extent of their tax compliance

\section{HYPOTHESES V}

$\mathrm{H}_{0}$; There is no significant relationship between the tax payers' confidence in the legal system and tax compliance.

$\mathrm{H}_{\mathrm{I}}$ : There is no significant relationship between the tax payers' confidence in the legal system and tax compliance.

\section{Scope And Limitation Of Study}

This study is limited to the study of organizations in the public, private and informal sectors of the Nigerian economy. These organizations are selected because they are duly registered with the Federal Inland Revenue Service and the Lagos State Internal Revenue Service for Pay As You Earn (PAYE). Further, the notes to their audited accounts show that, there has never been any negative report regarding tax evasion or tax avoidance. The limitation of this study, however, is in the area of methodological constraints in terms of which type of analytical technique is most appropriate for the work. In addition, because of funds and time constraint, the work is further limited to the selected organizations.

\section{History of Taxation in Nigeria Recent Tax Trend in Nigeria}

\section{Literature Review}

The Nigerian tax system is lopsided, and dominated by oil revenue. The most viable taxes are under the control of the Federal government while the lower tiers are responsible for the less buoyant ones. Nigeria is governed by a federal system, hence its fiscal operations also adhere to this system. This has serious implications on how the tax system is managed in the country. In Nigeria, the government's fiscal power is 
based on a three-tier tax structure divided among the Federal, State, and Local governments, each of which has different tax jurisdictions. As of 2002, about 40 (forty) different taxes and levies are shared by all three levels of government (Odusola, 2006). The first notable change in this modern trend was the Income Tax Management (Uniform Taxation Provisions) Decree No 7 of 1975. This unified reliefs and rates throughout the country, thus, resolving to some extent, the proliferation of various tax laws in the different states of the Federation.

The 1979 constitution vested the power to legislate on the taxation of income, profits and gains in the Federal Government with the effect that the various State tax laws were deemed to have become Federal tax laws. Subsequently, politics and sentiments dictated the action of Government. Pool tax, development rates, community tax and cattle tax were abolished even in States where it eventually became difficult, if not impossible, to pay workers' salaries, due to political expediency.

But as a result of the oil glut and subsequent decline in Federal Revenue and Statutory Allocation, many states hurriedly passed Sales Tax Laws in order to increase internally generated revenue. The oil glut did not abate even after the civilian administration was overthrown by the Military on $31^{\text {st }}$ December, 1983.

The Military Government that took over on $31^{\text {st }}$ December, 1983 inherited substantial decline in the main revenue source of the nation, which is oil. Therefore, the various state governments were encouraged to find ways of increasing internally generated revenue. The first step was a nationwide reorganization of the Revenue Department and the declaration of an open war, unprecedented in the history of taxation in Nigeria, on the social evil known as 'tax evasion'.

In 1985, the Federal Military Government promulgated the Miscellaneous Taxation Provision Decree, otherwise known as Decree 4. This law, among other things, increased personal allowance slightly, empowered tax authorities to request from any Bank any information about customers. From April 1, 1978, interest received by banks in respect of loan granted for agricultural trade or business and from April 1, 1980, for purposes of manufacturing goods for export were, up to December 31,1990, exempted from tax on graduated rates which varied between $40 \%$ and $100 \%$ depending on repayment and grace periods. From January 1, 1991 such interest is fully exempted from tax provided the moratorium period is not less than 18 months and the rate of interest on the loan is not more than the 'base lending rate' (that is 'weighted average of the cost of funds to a bank') at the time the loan was granted.

In 1992, the government introduced self assessment scheme, tax incentives to the Unit Trust to prevent double taxation and excess profit tax was abrogated. Furthermore, the 1992 amendments include: increase in personal income tax allowances, increase in the table of tax rates for personal income tax, introduction of rural investment allowance and treating Withholding Tax as an advance payment of tax - a reversal of the 1987 provision under the Income Tax Management Act. In 1993, the Personal Income Tax Decree 104 was promulgated which replaced the old Income Tax Management Act of 1961. The decree provided for increase in the table of rates for the taxation of individuals.

Corporate bodies are charged to tax under the Companies Income Tax Act of 1979 (as amended to date). However, while Nigerian companies are taxed on their worldwide income, foreign companies are liable only as regards the portion of their profits, which is attributable to business operations carried on in Nigeria. In addition to the company's income tax, all incorporated companies are required to pay $2 \%$ of their assessable profit into an Education Tax Fund in compliance with the Education Tax Act 1993 (as amended to date). Where a particular income or profit is chargeable to tax in Nigeria as well as in another country, there is a possibility of the taxpayer getting double taxation relief by way of tax credit under the provisions of the income tax statues. To this end, the Federal Government of Nigeria has negotiated and signed income tax treaties with some foreign countries which are intended to boost investment. For instance, the Industrial Development (Income Tax Relief) Act 1971 makes provisions for the grant of relief to pioneer companies. The pioneer status is granted mainly to companies in any industry which in the opinion of the National Council of Ministers, is urgently needed to achieve rapid economic growth. Also, a company which has incurred expenditure on its qualifying building and plant equipment in approved manufacturing activity in an Export Processing Zone is granted 100\% capital allowance in any year of assessment. This makes the cost of capital acquisition entirely deductible in the year in which the qualifying expenditure was incurred.

The Capital Gains Tax Act 1967 (as amended to date) charges to tax any capital gain accrued to individuals and corporate bodies whenever an asset is disposed.

Value Added Tax Act of 1993 (as amended to date) provided that all purchasers of chargeable goods and services are expected to pay 5\% of the purchase price as tax, the Value Added Tax Act is a federal statue and the tax is administered by the Federal Inland Revenue Service (an arm of the Federal Board of Inland Revenue) on behalf of the Federal, State and Local Governments. The proceeds are shared among the three tiers of government in accordance with a formula determine from time to time by the Federal legislature.

Another major source of revenue for the Federal Government is customs duty, which is payable by importers of specified goods. This tax is charged solely by the Federal Government and collected through the Nigeria Customs Service. Excise duty was levied on a variety of locally produced goods until 1998 when the tax 
was abolished. It was however partially reintroduced, with effect from January 1, 1999. The applicable law for customs and excise is the Customs and Excise Management Act 1958 (as amended to date).

The Stamp Duties Act 1939 (as amended to date) imposes tax on a wide range of documents and transactions. Where one of the parties is a corporate body, the tax is paid to the Federal Board of Inland Revenue. Others pay to the State tax authorities.

There are sundry levies and rates which local governments are authorized to collect. Notable here is the tenement rate payable annually on buildings situated within a particular local government area. This is levied by virtue of Tenement Rate Law of the various states. There is also a Development Levy payable at flat rate of N100 by individuals to the State governments. When real property is transferred, the relevant State government imposes some charges before the Governor grants his consent in accordance with the Land Use Act of 1978.

The Nigerian tax system features a mixture of direct and indirect taxes. All individuals, groups and corporate bodies that earned income, profits or gains, are affected, except for tenement rates payable on buildings, there is no tax on the ownership of capital assets. Capital gains tax is charged only when assets are disposed off at a profit. Virtually all the major taxes are within the exclusive legislative jurisdiction of the Federal Government, but the power to collect is often delegated to the States. The usual pattern is that federal authorities collect taxes from corporate bodies while States are allowed to collect from individuals and unincorporated groups. Even though local government authorities do not have substantive legislative powers, they charge and collect such rates and levies as may be authorized by statues of the relevant State government.

\section{Tax Morale}

Some preliminary tax morale research was conducted during the 1960s by the "Cologne School of Psychology" (Schmolders, 1960, Strumpel, 1969), who tried to narrow the bridge between economics and social psychology by emphasizing that economic phenomena should not only be analyzed from the traditional neoclassical point of view but also from social psychology perspective. In particular, they saw tax morale as an important and integral attitude that was related to tax noncompliance. There is still not enough empirical evidence about tax morale, defined as the intrinsic motivation to pay taxes, although many researchers including Frey (2003) and Torgler (2002) stress its relevance to understand the high observed level of compliance.

Three key factors are important in understanding tax morale: they are, moral rules and sentiments, fairness, and the relationship between taxpayer and government. These three key elements are important determinants in the empirical part of this study. Morale rules and sentiments focuses on social norms and discuss the four sentiments - guilt, shame, duty and fairness. A false declaration will generate anxiety, guilt, or if caught, shame and thus a prejudice to taxpayer's self-image. It is assumed that a taxpayer feels these moral costs which act as a restriction on non-compliance. On the other hand, if a taxpayer feels or believes that the tax system is unfair, that is, having a high tax burden, moral cost to behave honestly will decrease and tax evasion can be seen as a sort of resistance against the tax system.

The shared conviction of how people ought to behave is part of a society's social norms, therefore, it means that individuals will comply and pay taxes as long as they believe that compliance is a social norm ( Alm, McClelland and Schulze 1999).

Now, talking about fairness, an unfair tax system could enhance the incentives to rationalize cheating by taxpayers. Based on equity theory, it can be argued that taxpayer perceived their relationship with the state not only as a relationship of coercion, but also as one of exchange. Taxpayers are more inclined to pay or comply if the tax paid and government provision of social amenities are found to be equitable. The interaction between the taxpayer and the government is also a key determinant in this study because positive actions by the state are intended to increase taxpayer's positive attitudes and commitment not only to tax system, but also to tax payment, and thus, enhance compliant behaviour.

\section{The Concept of Tax Compliance}

Tax noncompliance describes a range of activities that are unfavorable to a state's tax system. These includes tax avoidance, which refers to reducing taxes by legal means, and tax evasion which refers which refers to the criminal non-payment of tax liabilities.

The groups that do not comply includes tax protesters and tax resisters. Tax protesters attempt to evade the payment of tax using frivolous interpretations of tax laws, whilst tax resisters refuse to pay a tax for some conscientious reasons (because the resisters do not want to support the government or some of its activities).

\section{The Concept Of Tax Avoidance}

This generally considered as a way of identifying the loophole in the tax laws and taking advantage of such a loophole to reduce the tax payable. e.g. a taxpayer may invest in qualifying capital expenditures that it will ordinarily not invest in because of the advantage it will take there from. Because of this, tax avoidance is 
not considered as an offence. A tax avoidance practices benefit the tax prayers at the expense of the state. The major loophole in the tax law is the area where companies enjoy capital allowances on their qualified capital expenditure. Capital allowance would be claimed on qualifying capital expenditures in use for the purpose of a trade or business. Capital allowance is claimed in replacement for depreciation charge, which is treated as an inadmissible expense for tax purpose. The tax benefits help them to have retained funds in the system to grow their businesses. Tax avoidance is legal. According to Sani (2005:54) tax avoider is simply one who agrees to his duties in such a way that he pays little or no tax.

\section{The Concept Of Tax Evasion}

Tax evasion is a deliberate Act on the part of the taxpayer not to pay tax due. This is considered as a criminal offence on the part of the taxpayer. The relevant tax authority may take such steps as it deems fit to recover any such tax and the taxpayer penalized if found guilty. Tax evasion can be partial or total and its degree varies from company to company. There is partial evasion when a company under declares its profits for tax purposes and total evasion of income tax occurs when a company which is already qualified to pay tax refuses to get its name registered in the tax roll. From the above mentioned, evasion of income tax is a serious problem in Nigeria, more so as there is a big gap between actual and potential tax collections by the various levels of government. The criminal act in Nigeria is perpetrated through these medium: total ignorance of the law, lack of faith in the ability of the government to use the money well, high tax rate which makes evasion more attractive and economical, absence of visible benefits accruing to the tax payers, outright unwillingness to contribute towards the development of the society, and the ridiculous low penalties prescribed in the laws for late payment of $\operatorname{tax}$

\section{Factors Affecting Compliance}

There is a clear need for more empirical research on the factors involved in the decision- making process regarding compliance, since a better understanding of these factors can give birth to strategies that improve compliance. This is specifically true for Nigeria, where there is little empirical evidence on which to base policy prescriptions. The following are factors affecting compliance;

\section{Honesty}

The contribution of enforcement, penalties, prices, income, and institutions limits the set of possibilities of individuals in the economy. Institutions can be formal such as constitutions, statute law, and regulations or informal, for example, self-enforced codes of behaviour, social norms and conventions in the society. Individuals create institution to set the limit of what people in a certain group are allowed to do, or alternatively, to determine under what condition people may not take certain actions. In general, institutions also establish criteria for punishment and sanctions. Individuals, from their expectations about the behaviour of the society, respects or obeys the laws. Based on these expectations, they will make their strategic choices. In the traditional model of tax compliance, this view of individual choices within a social environment is missing, only the threat of external sanction e.g. audits and penalties generate compliance. The fact that informal institutions can affect compliance has been excluded from the model. Furthermore, if it is true that the threat of external punishment is important, it is also true that informal institutions, such as codes of behavior and honesty can also constraint people's choices .If others behave according to a socially accepted mode of behaviour, the individuals will also comply and pay taxes as long as they believe that compliance is a social norm. Polinsky and Shavell (2000), present a survey of the economic theory of public enforcement of law, emphasize the aspect of social norm, that social norms can be seen as a general alternative to law enforcement in channeling individuals behaviour. However, some points remain unexplained- how do these norms arise in the first place and how can these norms be changed by deliberate government policies? There are limits for a government to increase compliance using traditional policies such as audits and fines. Therefore, if the government can influence a norm, tax evasion can be reduced by policy activities. Also, taxpayer may be aware that their evasion could damage the welfare of the community they live in. As a consequence, evasion can produce psychological costs. People may not be comfortable with dishonesty. However, when a taxpayer is convinced that he pays too much tax compared with the provided public goods, his psychological costs will be reduced.

In literature, there are two interesting theories that enable us to integrate moral constraints in a rational taxpayer model. The first theory is an altruistic approach (Chung 1976). Here taxpayers are not only interested in their own welfare but also concerned about the general welfare. The decision to evade is constrained by the knowledge that their evasion will reduce the amount of resources available for social welfare. The second is the "Kantian" morality approach (Sugden 1984). This approach broadly related to Kant's definition of morality, is based on assumption that a fair tax is a tax which a taxpayer believes to be fair for all to pay. A false declaration will generate anxiety, guilt or a reduction in taxpayer's image. It is assumed that a taxpayer feels these costs 
only if he believes that his tax share is not higher than what is defined fair. If he is paying a higher amount, evasion can be seen as a sort of self-defense.

\section{Guilt and Shame}

The process of being audited carries social risks, such as loss of reputation among family members, friends, and colleagues. In an extreme case, an audit can put the taxpayer's job at risk. People commonly discuss issues related to their taxes among family members and at their jobs. Grasmick and Bursik (1990) find that the feeling of shame and the loss of respect when people evade taxes are self imposed costs that decrease the likelihood of non-compliance.

They differentiate between shame and embarrassment. The former is something that the individual feels personally, it does not depend on others, while embarrassment includes pressure from family and significant others. According to Lewis (1971), guilt arises when individuals realize that they have acted irresponsibly and in relation to a rule or social norm they have institutionalized. Since the obligation of paying taxes to the government is an accepted social norm, it makes sense that individual who choose not to pay all of their taxes may feel guilty.

Aitken and Bonneville (1980) found in a Taxpayer Opinion Survey that over 50\% of the respondents claimed that their consciences would be bothered "a lot" after having engaged in any of the following activities;

(1) Padding business activities,

(2) Over stating medical expenses,

(3) Understating income,

(4) Not filing a return or

(5) Claiming an extra dependent.

Erard and Feinstein (1994) incorporate shame and guilt directly into the taxpayer utility. They hypothesized that a taxpayer feels guilty when he under-reports and escapes detection. He also feels ashamed when he underreports and caught. The problem with Erard and Feinstein's approach is that the taxpayer will not experience the threat of embarrassment if the people whose opinion is most value do not discover his crime. Thus, there is need to incorporate how the perceived probability of detection by significant others can also act as deterrent as well.

\section{Fairness}

Fairness is another factor that can affect tax compliance. An unfair tax system could enhance the incentives to rationalize cheating. A number of survey research studies have reported positive correlations between perceptions of fiscal inequity and tax evasion (Spicer 1974). Lack of equity in an exchange relationship creates a sense of distress, especially for the victim. Homes (1961) argued that disadvantage is followed by anger, advantage by guilt. Tax evasion may be seen as a reaction to restore equity.

Spicer and Becker (1980) in experimental research found that the amount of tax evaded increases when people are told that their tax burden is higher than that of the rest of the group. Nevertheless, there is no agreement regarding the empirical evidence on fairness.

Webley et al. (1991) found that there is no relation between perceived inequalities and compliance of the taxpayer. Bordignon (1993) introduced fairness as an additional motivation to the evasion decision. He rationalizes ethical norms by making them dependent on the tax structure, the supply of public goods, and the perceived behaviour of other taxpayers, The taxpayer's perception about the fairness of the system determines willingness to pay taxes; the more the tax burden and the provision of public goods differ

from an individual's moral idea, the less willing will he be to pay his taxes. Bordignon finds that there is a percentage of the population that does not evade, even when incentives exist to cheat.

Alm, McClelland and Schulze (1992) suggest that compliance occurs because some individuals value the public goods their tax finance. If there is an increase in the amount individuals receive from a given tax payment, their compliance rate increases. Individuals then pay taxes to receive government services even when there is no chance to be detected or punished when evading. Cowell (1992) shows that taxpayer will reduce tax evasion when perceiving equity. Falkinger (1995) has pointed out concrete economic situations in which individuals reduce evasion if the socio-economic system is considered to be relatively equal and fair. The fairness of a system in which a person lives may result in bad reputation for evaders if people consider evasion to be blameworthy, so that risk aversion will increase with perceived equity.

\section{A Social Identity Approach in Understanding Compliance}

This approach is based on understanding of processes of social identity (Tajel and Turner, 1986) and is a central perspective in social psychology. Turner (1985) developed a theory of self-categorization, in which he argued that self can be perceived as unique and individual, and is different in comparison with others ('me' in contrast to 'you/him/her'). 
At other times, however, self can be perceived as belonging to some social category (in-group), and relatively inter changeable with members of it, in contrast to another category to which self does not belong (out-group). This involves a psychological transformation from 'me' to 'we' and 'him/her' to 'them'. As the context changes ( that is- the issue, those involved, the frame of reference), so does self perception. It is when self perception is at the level of social identity, where greater similarity to in-group others and greater dissimilarity to output others is perceived, that, attitude and behaviour become more aligned with in- group norms.

Influence is argued to be an outcome of self-categorization and is specific to in -groups. Out-groups possess no ability to influence. That is, attitude, behaviour, perceptions of fairness, what is right and what is wrong are outcomes of, and vary with, self-categorization. Both personal and social identities are psychologically valid and meaningful expression of self. One is not regarded as more real or important than the other, rather, they are contextually-dependent and hence valid ( self definitions, driving attitudes and behaviour) given a particular context.

Perception "varies not only with the perceiver but also with the salient self-category for a given perceiver- different people see the same thing differently, and the same perceiver sees the same thing differently as the varying self changes" ( Turner and Oakes 1997). This analysis implies that self interest and civic virtue are not in direct competition with each other, rather self interest (that is, personal self interest) is likely to motivate behaviour when people see themselves as individuals ( in contrast with other individuals) while civic virtue ( what is good for the group collectively) is likely to motivate behaviour when people see themselves as being members of ( positively valued) social categories, in contrast to other ( negatively valued ) social categories. An appeal to civic virtue changes the psychological situation by putting the recipient in a wider, more inclusive category in a different social context.

In the McGraw and Scholz (1991) study, the appeal referred to the importance Americans place on norms of social responsibility and patriotism, emphasizing how these norms related to tax compliance. The context was manipulated to include 'all good American who believe in social responsibility and patriotism' (ingroup), which implied that not taking social responsibility seriously ( that is, not complying with tax rules) was essentially bad and un-American ( out-group).

On the assumption that most of the recipient would have regarded themselves as good Americans ( or at least would not have liked to think of themselves as bad American). This would have led to a self categorization of 'good American' thus, adopting more closely the attitudinal and behavioural norms associated with that category. At this super-ordinate level of identity, all Americans would then have the potential to be influential. This stems from the fact that those who are seen as similar to self are also perceived as more legitimate, fair, accurate and trustworthy ( Haslam,2001; Tyler, and Lind,1992).

Therefore, the appeal to civic virtue is associated with a qualitative shift in self-perception from 'me' to 'us', a corresponding shift in who is included in the frame of reference, and a corresponding decrease in personal self-interest and more certain about outcomes for all good Americans. It is due to the fact that attitudes, behaviours and motivations are outcomes of the self-categorization process that self-interest and civic virtue are not competing in a cost-benefit analysis. Whether self-interest or civic virtue will motivate behaviour will depend on whether personal or social identity is salient, and whether the salient social identity is one which includes a majority of people and groups within the self-concept ( a super-ordinate identity, such as 'American' ) or one which includes only a subset of people within the self concept (a subordinate identity, such as the 'rich' and the 'poor' ).

Most compliance with tax laws is to be expected at a more super-ordinate level of identity, because-that is the level at which most people are included in one's self definition and few people are excluded. Hence, if I perceive myself as American, then I care about America and Americans, and want what is best for Americans.

Least compliance with tax laws is to be expected at a more subordinate level of identity, because this level includes fewer people and is more likely to be situated in conflict with other subordinate groups ( for example, 'us poor versus them rich'), focusing the concern on distributive outcomes and maximizing the in -group's interests.

\section{Attitudes and Motivational Postures towards Tax.}

From the research conducted by Braithwaite and Braithwaite (2000), four motivational postures of taxpayers have been identified. These postures reflect underline values, attitudes and beliefs and are the result of the dynamic interplay between taxpayers and tax authorities. The motivational postures are referred to as 'commitment,' 'capture', 'resistance' and 'disengagement', and these embody psychological and behavioural orientations of taxpayers. 'Commitment' reflects a high level of internalized acceptance of the rules and regulations associated with tax system (meaning surveillance is unnecessary), while 'capture' reflects an explicit and conscious decision to comply, in the knowledge that tax authority has power and will use it if necessary. These motivational postures are both compliant. 
'Resistance' and 'disengagement' reflect a psychological increase in social distance between taxpayer and the regulatory system. Those who adopt these postures do not wish to be part of the tax system, are motivated to avoid it, and are more likely to engage in negative behaviour in relation to it. These postures, then, describe an escalating process of non-compliance, accompanied by escalations in the degree to which surveillance and punishment are necessary to produce compliance with tax regulation. Importantly, however, it is explicitly acknowledged that those motivational postures are not stable individual traits, but fluid, and taxpayers can shift between them. However, the specific processes which might lead to taxpayers adopting one motivational posture over another are not specified.

\section{Justice in Taxation Context}

People's behaviour is strongly linked to views about justice and injustice. Procedural justice in particular concerns the perceived fairness of the procedures involved in decision-making and the perceived treatment one receives from the decision maker. The procedural justice literature demonstrates that people's reactions to their personal experiences with authorities are rooted in their evaluations of the fairness of procedures those agencies use to exercise their authority. Actually people who feel they have been treated fairly by an organization will be more likely to trust that organization and be inclined to accept its decisions and follow its directions but people are most likely to challenge a situation collectively when they believe that the procedure is unfair.

The procedural justice literature specifically highlights the importance of an authority's trustworthiness, interpersonal respect, and neutrality in its dealings with others. If people believe that an authority is trying to be fair and to deal fairly with them, they trust the motives of that authority and develop a long-term commitment to accepting its decisions. Also research has shown that being treated politely, with dignity and respect, and having genuine respect shown for one's rights and social status, all enhance feelings of fairness.

\section{Theoretical Framework}

A theory is a statement of how and why specific facts are related. In this study, we present three theories and show their relevance for explaining tax morale and tax compliance. The approach of these theories is characterized by including a partially specific psychological effect to catch the relevance importance of an effect without losing the spirit of integrated psychological effect and without giving up economic foundations.

\section{Intrinsic Motivation Theory}

Other sciences like sociology and psychology have stressed the importance of behavior based on moral and ethical considerations. In economic analysis, internalized values are taken as exogenously given and not influenced by prices or regulations. ( Becker 1976 and Hirshleifer 1985). However, a view economists such as Hirschman (1965) and Sen (1977) took the relationship between external and internal motivation into account. Frey (1997) demonstrates that intrinsic versus extrinsic motivation are also relevant for explaining compliance behavior. He looks at tax morale as a particular kind of intrinsic motivation. It is an attempt to introduce a psychological effect into economics without giving up the rational choice framework. His approach includes a crowding out effect of intrinsic motivation in the analysis of tax compliance.

Increasing monitoring and penalties for noncompliance, individual will notice that extrinsic motivation has increased, which on the other hand crowds out intrinsic motivation to comply with taxes. Thus, the net effect of a stricter tax policy is unclear. If intrinsic motivation is not recognized, taxpayers get the feeling that they can as well be opportunistic. This puts into account the relevance of policy instruments in supporting or damaging the intrinsic motivation. Intrinsic motivation depends on the application of policy instruments. Frey (1997) claims that tax morale is not expected to be crowded out if the honest taxpayers perceive the stricter policy to be directed against dishonest taxpayers. Regulations which prevent free riding by others and establish fairness and equity help preserve tax morale.

\section{Ipsative Theory}

Under certain circumstances, human actions can be constrained by a set of possibilities which is considered to be relevant only for oneself. Other alternatives are disregarded (Frey and Foppa 1986). Frey (1997:196) calls it the "ipsative possibility set". The theory strongly relies on psychological evidence and can be seen as an attempt to model an aspect of human- imperfection. The ipsative possibility sets are characterized by Frey (1997) as:

(1) Non-marginal (alternatives are either considered fully or not at all)

(11) Asymmetric (alternatives outside the set are out of consideration) and

(111) Personal (relevant to certain person) 
Frey claims that an under-extension of the ipsative set is a common phenomenon among rational actors. Tax morale can be seen as such an issue, which is not open to a marginal but rather an absolute evaluation. There are taxpayers who do not even search for ways to cheat at taxes while others act contrarily. Relative price changes, by reason of higher punishment, are only considered by taxpayers with a low morality and can cheat. Frey even speaks of a perverse effect that arises when the government threatens citizen of high tax morality with increased punishment. Citizens can take this as an indication that the government does not honor compliant behavior. If the government distrusts them, tax morale can be undermined.

\section{Theory of Crime}

The deterrence doctrine can be traced back to the classical works of Jeremy Bentham and Cesare (Murphy 2008). Their classical utilization theory of crime is that people are rational actors who behave in a manner that will maximize their expected utility. Becker (1968) argued that authorities needed to and appropriately balance between detection of non-compliers and sanctions to the point where non-compliance becomes irrational.

In the early 1970s, Alligham and Sandmo (1972) extended Becker's work on the economics of crime to the taxation context. They examined taxpayer's decision to evade taxes when they were

filling out their tax returns and examined the relationship between penalty rate for tax evasion at the time, the probability of detection, and degree of tax evasion engaged in. What they found was that there was a relationship between these variables; with a higher penalty rate and probability of detection deterring individuals from evading their taxes. In the 1980s, therefore, many scholars began to question the value of deterrence alone in regulating behavior. They began to focus their attention on researching compliance rather than deterrence and began to realize the importance of persuasion and cooperation as a regulatory tool for gaining compliance. In fact, research has shown that the use of threat and legal coercion, particularly when perceived as illegitimate, can produce negative behavior; these actions are more likely to result in further non-compliance (Murphy and Harris 2007), creative compliance (McBarnet 2003), criminal behavior or opposition (Fehr and Rokenbach 2003).

\section{Population of study, Sample size and Sampling Technique}

The target population for this study comprised of employees who are 18 years and above, in the public and private sectors of the Nigerian economy. According to 2006 population census conducted by the National Population Commission, about 87 million Nigerians are of age 18 years and over. Therefore, the population size of approximately 87 million was relevant.

In view of the researcher's inability to reach out to the entire population, and in order to gain the advantage of an in-depth study and effective coverage, samples are drawn using random sampling from the six organizations. Yaro Yamani formula is used in determining the population size.

According to Yamani, (1964) $n=\mathrm{N} /\left[1+\left(\mathrm{Ne}^{2}\right)\right]$

Where $\mathrm{n}=$ is the sample size

$\mathrm{N}=$ is the population

$\mathrm{e}=$ is the error limit $(0.05$ on the basis of $95 \%$ confidence level $)$

Therefore, $\mathrm{n}=87,000,000 / 1+87,000,000(0.05)^{2}$

$$
\begin{aligned}
& \mathrm{n}=87,000,000 / 217500 \\
& \mathrm{n}=400
\end{aligned}
$$

Using a population of approximately $87,000,000$ Nigerians with an error limit of 5\%, a sample size of 400 is considered adequate as computed above. That notwithstanding, the study is based on a survey of 600 (six hundred) respondents drawn from a sample size of six organizations in the public and private sectors. The six organizations are Nigerian Airport Authority, Lagos State Ministry of Works (Public Organizations): First Bank Nigeria Plc., Globacom Nigeria Limited (Private Organizations): Oshodi Market and Mile-12 Markets (informal sector). The justification for choosing these organizations for the study is based on their unique role in the provision of social services and an avenue for gainful employment for the people. Further-more, a total number of 100 (one hundred) questionnaires was administered in each of the six chosen organizations.

\section{Sources of Data}

Primary data collection is necessary when a researcher cannot find the data needed from secondary sources, especially when the researcher is interested in primary data about demographic/socioeconomic characteristics, attitude/opinion/interest, awareness/knowledge, intentions, motivation and behavior. The three basic means of obtaining primary data are observations, surveys, and experiments. The study adopted the primary sources of data collection by survey research design.

\section{Research Methodology}

Regression analysis was used to test the hypotheses. The model is shown below: 
The Regression Model:

(1) TMOR $=\alpha_{\mathrm{O}}+\beta_{1} \mathrm{SON}+\beta_{2} \mathrm{ATG}+\beta_{3} \mathrm{ATTEV}+\beta_{4} \mathrm{ATTAV}+\beta_{5} \mathrm{ATLS}+\beta_{6} \mathrm{OTTI}+\varepsilon$

(2) $\quad \mathrm{ATTCOM}=\mathrm{TMOR}+\varepsilon$

Where:

TMOR $=$ Tax Morale

$\mathrm{SON}=$ Social Norms

ATG $=$ Attitude of Taxpayer towards Government

ATTEV $=$ Attitude of Taxpayer towards Tax Evasion

ATTAV = Attitude of Taxpayer towards Tax Avoidance

ATLS $=$ Attitude of Taxpayer towards Legal System

OTTI $=$ Obedience of Taxpayers to Traditional Institution

ATTCOM = Attitude of Taxpayer towards Tax Compliance

$\varepsilon=$ Is the error term

MODEL TMOR $=\mathrm{a}_{\mathrm{o}}+\beta_{1} \mathrm{SON}+\beta_{2} \mathrm{ATG}+\beta_{3} \mathrm{ATTEV}+\beta_{4} \mathrm{ATTAV}+\beta_{5} \mathrm{ATLS}+\beta_{6} \mathrm{ATTI}+\varepsilon$

Where TIMOR is the tax morale, SON is the social norms, ATG is the attitude towards government, ATTEV is the attitude towards tax evasion, ATTAV is the attitude towards tax avoidance, ATLS is the attitude of tax payers towards legal system, ATTI is the attitude towards traditional institutions and $\varepsilon$ is the error term.

Table 4.3..1 Variables Entered / Removed (b)

\begin{tabular}{|l|l|l|l|}
\hline Model & Variables Entered & Variables Removed & Method \\
\hline 1 & Social Norms (SON) & & \\
& Attitude Towards Government (ATG) & & \\
& Attitude Towards Tax Evasion (ATTEV) & & \\
& Attitude Towards Tax Avoidance (ATTAV) & & \\
& Attitude Towards Legal System (ATLS) & & \\
\hline & Attitude Towards Traditional Institution (ATTI) & & \\
\hline
\end{tabular}

Source: Field Study (2012)

a. All requested variables entered

b. Dependent variables: Tax Morale TMOR

Table 4.3.2 Pearson Correlations

\begin{tabular}{|c|c|c|c|c|c|c|c|}
\hline Pearson & TMOR & SON & ATG & ATTEV & ATTAV & ATLS & ATTI \\
\hline ATG & -.104 & -.078 & 1.000 & .008 & -.151 & .552 & .042 \\
\hline ATTAV & .359 & .149 & -.151 & .304 & 1.000 & -.131 & .150 \\
\hline ATLS & -.136 & -.044 & .552 & -.104 & -.131 & 1.000 & .025 \\
\hline ATTI & .065 & .223 & .042 & .200 & .150 & .025 & 1.000 \\
\hline ATG & .036 & .088 & & .446 & .004 & .000 & .233 \\
\hline ATTEV & .000 & .000 & .446 & & .000 & .036 & .000 \\
\hline ATTAV & .000 & .005 & .004 & .000 & & .011 & .005 \\
\hline ATLS & .009 & .224 & .000 & .036 & .011 & & .335 \\
\hline ATTI & .132 & .000 & .233 & .000 & .005 & .335 & \\
\hline
\end{tabular}

Source: Field Study (2012)

Table 4.3.3 Model Summary

\begin{tabular}{|c|c|c|c|c|c|c|c|c|c|}
\hline & & & & & \multicolumn{4}{|c|}{ Change Statistics } \\
Model & $\mathbf{R}$ & \multirow{2}{*}{$\begin{array}{c}\text { R } \\
\text { Square }\end{array}$} & \multirow{2}{*}{$\begin{array}{c}\text { Adjusted R } \\
\text { Square }\end{array}$} & $\begin{array}{l}\text { Std. Error } \\
\text { of the } \\
\text { estimate }\end{array}$ & $\begin{array}{c}\text { R Square } \\
\text { Change }\end{array}$ & $\begin{array}{c}\text { F } \\
\text { Change }\end{array}$ & df1 & df2 & $\begin{array}{c}\text { Sig. of } \\
\text { Change }\end{array}$ \\
\hline 1 & .460 & .212 & .196 & 6.15697 & .212 & 13.138 & 6 & 293 & .000 \\
\hline
\end{tabular}

Source: Field Study (2012)

a. Predictors: (Constant), SON, ATG, ATTEV, ATTAV, ATLS, ATTI

Table: 4.3.4 ANOVA (b)

\begin{tabular}{|l|c|c|c|c|}
\hline \multicolumn{1}{|c|}{ Model } & Sum of Square & df & Mean Square & F \\
\hline Regression & 2988.257 & 6 & 498.043 & 13.138 \\
Residual & 11107.113 & 293 & 37.908 & .000 \\
Total & 14095.370 & 299 & & \\
\hline
\end{tabular}


Source: Field Study (2012)

a. Predictors: (Constant) SON, ATG, ATTEV, ATTAV, ATLS, ATTI

b. Dependent Variable: Tax Morale (TIMOR)

Table: 4.3.5 Co-efficients (a)

\begin{tabular}{|c|c|c|c|c|c|}
\hline \multirow[t]{2}{*}{ Model } & \multicolumn{2}{|c|}{$\begin{array}{l}\text { Unstandardized } \\
\text { Coefficients }\end{array}$} & \multirow{2}{*}{$\begin{array}{c}\begin{array}{c}\text { Standardized } \\
\text { Coefficients }\end{array} \\
\text { Beta }\end{array}$} & \multirow{2}{*}{$\mathbf{t}$} & \multirow{2}{*}{ Sig. } \\
\hline & B & Std. Error & & & \\
\hline (Constant) & 6.519 & 2.176 & & 2.995 & .003 \\
\hline Social Norm (SON) & .199 & 0.41 & .279 & 4.849 & .000 \\
\hline Attitude towards government (ATG) & -.029 & .227 & -.008 & -.126 & .900 \\
\hline Attitude towards tax evasion (ATTEV) & .288 & .079 & .218 & 3.653 & .000 \\
\hline Attitude towards avoidance (ATTAV) & .887 & .198 & .254 & 4.471 & .000 \\
\hline Attitude towards legal system (ATLS) & -.212 & .217 & -.062 & -.980 & .328 \\
\hline $\begin{array}{l}\text { Attitude towards traditional institution } \\
\text { (ATTI) }\end{array}$ & -.090 & .065 & -.077 & -1.394 & .164 \\
\hline
\end{tabular}

Source: Field Study (2012)

a. Dependent Variable: Tax Morale

As can be observed from table 4.3.4, the p-value of F-test is statistically significant which means at p-value of zero to three decimal places, the model is statistically significant.

The p-value associated with the F value is very small (.000) and when compared with our alpha level of 0.05 we can conclude that the independent variables reliably predict the dependent variable. If the p-value were greater than 0.05 , we would say that the group of independent variables do not show a significant relationship with the dependent variable, or that the group of independent variables do not reliably predict the dependent variable. The ability of each individual independent variable to predict the dependent variable is addressed in table 4.3.5. The R-square in table 4.3 .3 is .212, this means that, approximately $21 \%$ of the variability of TMOR (Tax Morale) is accounted for by the variables in the model. (That is; social norms, attitude towards government, attitude towards tax evasion, attitude towards tax avoidance, attitude towards legal system and attitude towards traditional institutions).

The adjusted R-squared as shown in table 4.3 .3 indicates that about $20 \%$ of the variability of Tax Morale (TMOR) is accounted for by the model, even after taking into account the number of predictor variables in the model.

The coefficients for each of the variables as shown in table 4.3.5, indicates the amount of change one could expect in TMOR (Tax Morale) given a one unit change in the value of that variable, given that all other variables in the model are held constant. Therefore, we would expect an increase of 0.20 (approximately) in TMOR (Tax Morale) score for every one unit increase in SON (Social Norms) assuming that all other variables in the model are held constant. Also, we would expect a decrease of 0.03 in TMOR (tax morale) score for every one unit increase in ATG (attitude towards government) assuming that all other variables in the model are held constant.

From attitude towards tax evasion (ATTEV), we would expect an increase of 0.29 (approximately) in TMOR score (tax morale) for every one unit increase in ATTEV, assuming that all other variables in the model are held constant. Again from table 4.3.5, we would expect an increase of 0.89 (approximately) in TMOR (Tax Morale) score for every one unit increase in ATTAV, assuming that all other variables in the model are held constant.

A one unit increase in ATLS (attitude towards legal system) and ATTI (attitude towards traditional institutions) would lead to 0.21 and 0.09 decrease in TMOR score (tax morale) respectively assuming that all other variables in the model are held constant.

In table 4.3.5, the column of Beta coefficients help us to compare the strength of the coefficient of one independent variable with the other. These are the values for a regression equation if all of the variables are standardized to have a mean of zero (0) and a standard deviation of one (1). Because the standardized variables are all expressed in the same units, the magnitudes of the standardized coefficients indicate which variables have the greatest effects on the predicted (dependent) value.

In this study, Social Norm (SON) has the largest Beta Coefficient, .279 and attitude towards government (ATG) has the smallest Beta Coefficient, -.008. Thus, a one standard deviation increase in SON leads to a .279 standard deviation increase in predicted (TMOR) with the other variables held constant. And a one standard deviation increase in ATG, in turn, leads to a .008 standard deviation decrease in TMOR with the other variables in the model held constant.

The difference between the regular co-efficient (unstandardized) and the standardized coefficient is the units of measurement. For example, to describe the raw coefficient for social norm (SON), we say a one-unit 
increase in SON would yield a .199 increase in the predicted (TMOR). However, for the standardized coefficient (BETA) we say a one standard deviation increase in social norm (SON) would yield a .279 standard deviation increase in the predicted (TMOR).

As shown in table 4.3.5, the coefficient for social norm (SON) is significantly different from 0 using alpha of 0.05 because its p-value of .000 is smaller than 0.05 . The coefficient for attitude towards government (ATG) is not significantly different from 0 using alpha of 0.05 because its $p$ value of .900 is greater than 0.05 . The coefficient for attitude towards tax evasion (ATTEV) is significantly different from 0 using alpha of 0.05 because its $p$ value of .000 is smaller than 0.05

The coefficient of attitude towards tax avoidance (ATTAV) is significantly different from 0 using alpha of 0.05 because its p-value of .000 is smaller than 0.05 . The coefficient of attitude towards legal system is not significantly different from 0 using alpha of 0.05 because its p-value of .328 is greater than 0.05 . The coefficient of attitude towards traditional institution (ATTI) is not significantly different from 0 using alpha of 0.05 because its $p$ value of .164 is greater than 0.05

\section{MODEL 2:}

$\operatorname{ATTCOM}=\mathrm{a}_{0}+\beta_{1}$ TMOR $+\varepsilon$

Where ATTCOM is attitude towards tax compliance and TMOR is tax morale

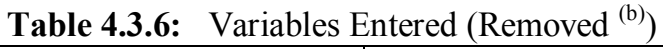

\section{Source: Field Study (2012)}

\begin{tabular}{|c|c|c|c|}
\hline Model & Variables Entered & Variables Removed & Method \\
\hline 1. & Tax Morale ${ }^{(a)}$ & & Enter \\
\hline
\end{tabular}

a. All requested variables entered

b. Dependent variables: Attitude towards tax compliance

Table 4.3.7: Pearson Correlations

\begin{tabular}{|l|c|c|}
\hline \multicolumn{1}{|c|}{ Pearson } & Attitude Towards Tax compliance & Tax Morale \\
\hline & & \\
Attitude towards Tax compliance & 1.000 & .187 \\
Tax Morale & .187 & 1.000 \\
\hline $\begin{array}{l}\text { Sig. (1-tailed) } \\
\text { Attitude towards Tax compliance }\end{array}$ & & .001 \\
Tax Morale & .001 & \\
\hline
\end{tabular}

Table 4.3.8: Model Summary

\begin{tabular}{|c|c|c|c|c|c|c|c|c|c|}
\hline \multirow{2}{*}{ Model } & \multirow{2}{*}{$\mathbf{R}$} & \multirow{2}{*}{ R Square } & \multirow[b]{2}{*}{$\begin{array}{c}\text { Adjusted R } \\
\text { Square }\end{array}$} & \multirow[b]{2}{*}{$\begin{array}{c}\text { Std. Error } \\
\text { of the } \\
\text { estimate }\end{array}$} & \multicolumn{5}{|c|}{ Change Statistics } \\
\hline & & & & & $\begin{array}{c}\text { R Square } \\
\text { Change }\end{array}$ & F Change & df1 & df2 & $\begin{array}{l}\text { Sig. Of } \\
\text { Change }\end{array}$ \\
\hline 1 & $.187^{\mathrm{a}}$ & .035 & .032 & 4.89384 & .035 & 10.762 & 1 & 298 & .001 \\
\hline
\end{tabular}

Source: Field Study (2012)

a.

Predictors: (Constant), Tax Morale

Table: 4.3 .9

ANOVA $^{(b)}$

\begin{tabular}{|l|c|c|c|c|c|}
\hline \multicolumn{1}{|c|}{ Model } & Sum of Square & df & Mean Square & F & Sig. \\
\hline Regression & 257.735 & 1 & 257.735 & 10.762 & $.001^{\text {a }}$ \\
Residual & 7136.995 & 298 & 23.950 & & \\
Total & 7394.730 & 299 & & & \\
\hline
\end{tabular}

Source Field Study (2012)

a. Predictors: (constant) Tax Morale

b. Dependent Variable: Attitude towards Tax Compliance

Table: $4.3 .10 \quad$ Coefficients $^{\text {(a) }}$

\begin{tabular}{|c|c|c|c|c|c|}
\hline \multirow{2}{*}{ Model } & \multicolumn{2}{|c|}{ Unstandardized Coefficient } & Standardized Coefficient & \multirow{2}{*}{ t } & \multirow{2}{*}{ Sig. } \\
\cline { 2 - 5 } & B & Std. Error & Beta & & \\
\hline & & & & 20.732 & .000 \\
1. (Constant) & 16.149 & .779 & .187 & 3.280 & .001 \\
Tax Morale & .135 & .041 & & \\
\hline
\end{tabular}

Source: Field Study (2012) 
a. Dependent Variable: Attitude towards Tax Compliance

From Table 4.3.9, we observed that the p-value of f-test is statistically significant, which means with a p-value of .001, the model is statistically significant. The R-square in table 4.3 .8 is .035 this means that, approximately $4 \%$ of the variability of tax compliance (ATTCOM) is accounted for by variable in the model that is, TMOR (tax morale).

The adjusted R-square as shown in table 4.3 .8 indicates that about $3 \%$ of the variability of tax compliance is accounted for by the model.

The coefficient for the variables as shown in table 4.3.10 indicates the amount of change one could expect in ATTCOM (tax compliance) given a one unit change in the value of that variable. Therefore, we would expect an increase of approximately $14 \%$ in tax compliance (ATTCOM) score for every one unit increase in tax morale (TMOR). Also, a one standard deviation increase in TMOR (tax morale) leads to a .187 standard deviation increase in ATTCOM (tax compliance).

The coefficient for tax morale (TMOR) as shown in table 4.3.10 is significantly different from 0 using alpha of 0.05 because its p-value of .001 is smaller than 0.05 .

Table 4.3.11 shows the correlations among the variables in the regression model 1

Table 4.3.11 Correlations

\begin{tabular}{|c|c|c|c|c|c|c|c|c|}
\hline & $\begin{array}{c}\text { Tax } \\
\text { Moral } \\
\text { e }\end{array}$ & $\begin{array}{c}\text { Social } \\
\text { Norms }\end{array}$ & $\begin{array}{c}\text { Trust in } \\
\text { Govt. }\end{array}$ & $\begin{array}{c}\text { Tax } \\
\text { Evasion }\end{array}$ & $\begin{array}{c}\text { Tax } \\
\text { Avoidance }\end{array}$ & $\begin{array}{c}\text { Trust } \\
\text { in } \\
\text { Legal } \\
\text { system }\end{array}$ & $\begin{array}{l}\text { Traditional } \\
\text { Institutions }\end{array}$ & $\begin{array}{c}\text { Tax } \\
\text { Complianc } \\
\mathrm{e}\end{array}$ \\
\hline Tax Morale & 1 & $\begin{array}{l}-.009 \\
.873\end{array}$ & $\begin{array}{l}.000 \\
.990\end{array}$ & $\begin{array}{l}.080 \\
.166\end{array}$ & $\begin{array}{l}.023 \\
.697\end{array}$ & $\begin{array}{l}.132^{\mathrm{x}} \\
.022\end{array}$ & $\begin{array}{l}.044 \\
.446\end{array}$ & $\begin{array}{l}.151^{\mathrm{xx}} \\
.009\end{array}$ \\
\hline $\begin{array}{l}\text { Social } \\
\text { Norms }\end{array}$ & $\begin{array}{l}-.009 \\
.873\end{array}$ & 1 & $\begin{array}{l}-.020 \\
.733\end{array}$ & $\begin{array}{c}-.230^{\mathrm{xx}} \\
.000\end{array}$ & $\begin{array}{l}.191^{\mathrm{xx}} \\
.001\end{array}$ & $\begin{array}{l}-.073 \\
.205\end{array}$ & $\begin{array}{c}-.248^{\mathrm{xx}} \\
.000\end{array}$ & $\begin{array}{l}.076 \\
.191\end{array}$ \\
\hline $\begin{array}{l}\text { Trust in } \\
\text { Government }\end{array}$ & $\begin{array}{l}.000 \\
.990\end{array}$ & $\begin{array}{c}-.020 \\
.733\end{array}$ & 1 & $\begin{array}{l}.176^{\mathrm{xx}} \\
.002\end{array}$ & $\begin{array}{c}-.151^{\mathrm{xx}} \\
.009\end{array}$ & $\begin{array}{l}.552^{\mathrm{xx}} \\
.000\end{array}$ & $\begin{array}{l}.169^{\mathrm{xx}} \\
.003\end{array}$ & $\begin{array}{l}.118^{\mathrm{x}} \\
.041\end{array}$ \\
\hline $\begin{array}{l}\text { Tax } \\
\text { Evasion }\end{array}$ & $\begin{array}{l}.080 \\
.166\end{array}$ & $\begin{array}{c}-.230^{\mathrm{xx}} \\
.000\end{array}$ & $\begin{array}{l}.176^{\mathrm{xx}} \\
.002\end{array}$ & 1 & $\begin{array}{l}.167^{\mathrm{xx}} \\
.004\end{array}$ & $\begin{array}{l}.148^{\mathrm{x}} \\
.010\end{array}$ & $\begin{array}{l}.313^{\mathrm{xx}} \\
.000\end{array}$ & $\begin{array}{l}.126^{\mathrm{x}} \\
.030\end{array}$ \\
\hline $\begin{array}{l}\text { Tax } \\
\text { Avoidance }\end{array}$ & $\begin{array}{l}0.23 \\
.697 \\
\end{array}$ & $\begin{array}{l}.191^{\mathrm{xx}} \\
.001 \\
\end{array}$ & $\begin{array}{c}-.151 \\
.009 \\
\end{array}$ & $\begin{array}{l}.167^{\mathrm{xx}} \\
.004\end{array}$ & 1 & $\begin{array}{c}-131^{\mathrm{xx}} \\
.023\end{array}$ & $\begin{array}{l}.169^{\mathrm{xx}} \\
.003\end{array}$ & $\begin{array}{l}.065 \\
.264 \\
\end{array}$ \\
\hline $\begin{array}{l}\text { Legal (trust) } \\
\text { System }\end{array}$ & $\begin{array}{l}.132^{\mathrm{x}} \\
.022\end{array}$ & $\begin{array}{l}-.073 \\
.205\end{array}$ & $\begin{array}{l}.552^{\mathrm{xx}} \\
.000\end{array}$ & $\begin{array}{l}.148^{\mathrm{x}} \\
.010\end{array}$ & $\begin{array}{l}-.131^{\mathrm{x}} \\
.023\end{array}$ & 1 & $\begin{array}{l}.123^{\mathrm{x}} \\
.033\end{array}$ & $\begin{array}{l}.358^{\mathrm{xx}} \\
.000\end{array}$ \\
\hline $\begin{array}{l}\text { Traditional } \\
\text { Institutions }\end{array}$ & $\begin{array}{l}.044 \\
.446\end{array}$ & $\begin{array}{c}-.248^{\mathrm{xx}} \\
.000\end{array}$ & $\begin{array}{l}.169^{\mathrm{xx}} \\
.003\end{array}$ & $\begin{array}{l}.313^{\mathrm{xx}} \\
.000\end{array}$ & $\begin{array}{c}-.169^{\mathrm{xx}} \\
.003\end{array}$ & $\begin{array}{l}.123^{\mathrm{x}} \\
.033\end{array}$ & 1 & $\begin{array}{l}-.040 \\
.491\end{array}$ \\
\hline $\begin{array}{l}\text { Tax } \\
\text { Compliance }\end{array}$ & $\begin{array}{l}.151^{\mathrm{xx}} \\
.009\end{array}$ & $\begin{array}{l}.076 \\
.191\end{array}$ & $\begin{array}{l}.118^{\mathrm{x}} \\
.041\end{array}$ & $\begin{array}{l}.126^{\mathrm{xx}} \\
.030\end{array}$ & $\begin{array}{l}.065 \\
.264\end{array}$ & $\begin{array}{l}.358^{\mathrm{xx}} \\
.000\end{array}$ & $\begin{array}{c}-.040 \\
.491\end{array}$ & 1 \\
\hline
\end{tabular}

Source: Field Study (2012)

$\mathbf{x}$ Correlation is significant at the 0.05 level (2-tailed)

$\mathbf{x x}$ Correlation is significant at the 0.01 level (2-tailed)

Table 4.3.11 shows that there are a number of significant correlations between tax compliance and tax morale, trust in government, tax evasion and trust in legal system. There are significant correlations $(\mathrm{p}<.01)$ between tax compliance and trust in legal system $(\mathrm{r}=.36)$, tax compliance and tax morale $(\mathrm{r}=.15)$, tax compliance and tax evasion $(\mathrm{r}=.13)$. Correlations is also found $(\mathrm{p}<.05)$ between tax compliance and trust in government $(\mathrm{r}=$ .12). However, insignificant correlations are found between tax compliance and social norms; tax compliance and tax avoidance; and tax compliance and traditional institutions. These results provide support for Hypothesis 1,2 and 5 of this study and at the same time do not support Hypothesis 3 and 4.

HYPOTHESIS 1

Tax Morale has no significant effect on tax payers compliance.

For this hypothesis, the result of simple regression analysis was used as can be observed from table 4.3.8. The $\mathrm{R}$ square which measures the explained variance in the model is .032 and is significant at 0.05 level, also in table 4.3.11. There is a significant correlation (2-tailed) between tax compliance and tax morale $(\mathrm{r}=15)$ at 0.01 level. Going by this result we reject the null hypothesis and accept the alternate hypothesis. In other words, we accept that tax morale has, a statistically significant effect on tax payers compliance

\section{HYPOTHESIS 2}

There is no significant relationship between trust in government and tax compliance.

The result of the 2 tailed Pearson correlations presented in table 4.3.11 was used in testing this hypothesis. As can be observed from the table, there is a significant correlation between tax compliance and trust in government $(\mathrm{r}=.12)$ at 0.05 level.

Therefore, with this result, we reject the null hypothesis and accept the alternate. In other words, we accept that there is statistically significant relationship between trust in government and tax compliance. 


\section{HYPOTHESIS 3}

There is no significant relationship between the Nigerian Traditional Institutions and tax compliance. The result as shown in table 4.3.11 indicates that, there is no significant relationship between the Nigerian Traditional Institution and tax compliance at both 0.05 and 0.01 levels. By this result, we accept the null hypothesis and reject the alternate. In other words, we accept that there is no statistically significant relationship between the Nigerian Traditional Institutions and Tax compliance.

\section{HYPOTHESIS 4}

There is no significant relationship between Tax payers cultural norms and extent of their tax compliance.

As can be observed from table 4.3.11, there is no significant relationship between social norms and tax compliance at both 0.05 and 0.01 levels. This result, thus support the null hypothesis, based on which we accept it as stated.

\section{HYPOTHESIS 5}

There is no significant relationship between tax payers confidence in the legal system and tax compliance The result presented in table 4.3.11 shows that, there is a significant relationship ( 2 tailed) between the tax payers' confidence in the legal system and tax compliance at 0.01 levels. By this result, we reject the null hypothesis and accept the alternate. In other words, we accept that there is a statically significant relationship between the tax payers confidence in the legal system and tax compliance.

\section{Summary Of Findings Conclusion And Recommendations}

\section{Summary of Theoretical Findings}

According to the traditional model of tax compliance by Allingham and Sandmo, taxpayers choose how much income to report on their tax by solving a standard expected utility maximization problem that trade off the tax savings from underreporting true income against the risk of audit and penalties for detected noncompliance. In this framework, threat of penalty and audit influence people to pay their taxes (Allingham and Sandmo, 1972).

Tax morale is defined as the "intrinsic motivation to pay taxes". Torgler (2002) and Fred (2003) stress its relevance to understand the high-observed level of compliance. Three key factors are important in understanding tax morale: moral rule and sentiments, fairness and the relationship with government. According to James, Murphy and Reinhart (2005), tax laws cannot cope with every eventuality and have to be supplemented with administrative procedures and decisions and just as importantly, in order to work, it has to have a reasonable degree of willing compliance on the part of the taxpayers themselves.

Tax compliance may be seen in terms of tax avoidance and evasion. The two are conventionally distinguished in terms of legality, with avoidance referring to legal measures to reduce tax liability and evasion as illegal measures. Compliance might therefore be better defined in terms of compliance with the spirit as well as the letter of the law (James, Murphy and Reinhart 2005).

The shared conviction of how people ought to behave is part of a society's social norms, therefore, it means that individuals will comply and pay taxes as long as they believe that compliance is a social norm (Alm, McClelland and Schulze 1999).

According to James, Murphy and Reinhart (2005), "tax laws cannot cope with every eventuality and have to be supplemented with administrative procedures and decisions and just as importantly, in order to work, it has to have a reasonable degree of willing compliance on the part of the taxpayers themselves." Therefore, a more appropriate definition could include the degree of compliance with tax laws and administration that can be achieved without the immediate threat or actual application of enforcement activity.

Tyler (1997) argues that understanding what people want in a legal procedure help to explain public dissatisfaction with the law and points towards directions of building public support for the law in the future. Therefore, taxpayers, when they are treated fairly and respectfully by the tax authorities, tend to cooperate better. Another perspective admits the relationship between the taxpayer and the government, where elements such as government performance, public goods, the impact of public expenditure, and the taxpayer's internal motivation affect tax compliance decisions. Taxpayers will refuse to pay their taxes if they feel that the government is wasting their money. Looking to connect the performance of the government with the satisfaction of the taxpayer, Cowell and Gordon (1988) link the two sides of the government budget, income and expenditure, by introducing public goods.

In a study of Australian taxpayers, Wenzel (2002) also studied the impact of justice perceptions, but this time on self-reported tax compliance. Using a survey methodology, Wenzel found that the taxpayers were more compliant when they thought that they had been treated fairly and respectably. If individuals trust the 
motives of authorities, feel that they behave neutrally, and feel treated with respect and dignity, it appears they will be more willing to cooperate with the authorities and obey their decisions.

Richardson, (2006) found complexity to be another important determinant of tax morale. He concluded in his study that, the lower the level of complexity and the higher the level of general education, the higher is the level of tax morale

Summary of Empirical Finding

The study covered the interactions between tax morale on one-hand and predictor variables (social norms, attitude towards government, attitude towards tax evasion, tax avoidance, legal system, tax compliance and attitude towards traditional institutions) on the other hand. The main objective of the study was to determine the effect of tax morale on the taxpayer in compliance to tax policies of government in Nigeria. Survey design was used with questionnaire as the major tool of data collection. Questionnaires were administered to 600 randomly selected respondents and $50 \%$ of these returned their questionnaires.

As can be observed from Table 4.3.4, the p-value of f-test is statistically significant, which means with a p-value of zero to three decimal places, the model 1 is statistically significant. The R-square in table 4.3.3 is .212 , this means that, approximately $21 \%$ of the variability of tax morale (TMOR) is accounted for by the variables in the model. The adjusted R-square as showing in table 4.3 .3 indicates that $20 \%$ of the variability of tax morale (TMOR) is accounted for by the model, even after taking into account the number of predictor variables in the model.

Table 4.3.9 shows the result of model 2. From the table the p-value of F-test is statistically significant, which means with a p-value of .001 , the model is statistically significant. The R-square in table 4.3.8 is .035; this means that approximately $4 \%$ of the variability of tax compliance is accounted for by variable in the model. Table 4.3.11 shows the (2-tailed) correlations among the variables in the regression model 1. Observation from this table shows that there are a number of significant correlations between tax compliance and tax morale, trust in government, tax evasion and trust in legal system. However, insignificant correlations are found between tax compliance and social norms, tax avoidance and traditional institutions. In this study, all the predictors were found to have varying degrees of predictive power on the criterion variables.

\section{Conclusion}

While tax morale has been an academic research topic in most developed countries, there has not been detailed consideration of the major determinants of tax morale in Nigeria. This is a pioneer study on tax morale and tax compliance in Nigeria. Also for the first time in the study of tax morale this work analyzes the effect of traditional institutions (monarch) on tax morale. Our empirical findings indicate that social norms, attitude towards government, tax evasion and tax avoidance have significant effect on tax morale. On the other hand, there is no significant effect of attitude towards legal system and traditional institutions on tax morale. We also established a significant positive effect of tax morale on tax compliance.

This study can be seen as one that incorporates non-economic factors into the economic analysis of tax compliance. Tax compliance is not just a function of opportunity, tax rates, probability of detection and so on but of each individual's willingness to comply shaped by tax morale. This means that if tax morale is high, tax compliance will be relatively high.

Tax payers may follow laws they know or trust to produce good results. But laws are not only chosen according to past experiences; they are also influenced by the attributions tax payers give to them (for example, fairness and efficiency). Putting into consideration that a society is heterogeneous, a person's type plays an important role in determining which laws are followed and which are not. In general tax payers are more inclined to comply with the laws if the relationship between the tax paid and the performed government services is found to be equitable. Thus, government and tax administration's strategy aimed at creating confidence in their credibility and their capacity is rewarded with higher tax morale.

\section{Recommendations}

This study has brought to the fore the imperative of tax morale in the achievement of high tax compliance. Based on the findings in this study, we hereby make recommendations that may guide programmes, policy formulation and implementation of government that seek to increase tax payers level of tax compliance.

(i) If taxpayers do not understand what their obligations are, any intervention to enforce compliance will be perceived as unfair. Thus, there is a need to provide strong taxpayer's services particularly during the tax filing stage. This will include dissemination of information in order to enhance taxpayer compliance and also introduce taxpayer education programmes. Taxpayer's service can also be improved by: providing proper guidance on how the tax return forms are to be completed correctly, introducing automated systems to record and answer tax payers' queries and wider use of the mass media to publicize important tax deadlines and so on.

(ii) The capability to detect fraud or evasion is crucial to tax compliance. As it would not be practical to audit all cases, the fear of being caught would be sufficient to act as a deterrent. Ideally, when a case is selected 
for audit a tax official will be required to visit the premises of the taxpayer. The tax returns will have to be scrutinized under the supervision, or be jointly examined with a senior tax official so that the discretionary powers being exercised by tax officials are not abused. The tax authorities should undertake criminal prosecution in respect of cases involving fraud or evasion, and where appropriate publish the names of tax evaders which will act as a deterrent

(iii) It is very important to educate the young (who are the next generation of taxpayers) on the significance and role of taxes. There is need to create an environment for tax education in schools through the establishment of councils for promotion of tax education. Tax education should be viewed in the medium and long-term perspectives, and as a means to enhance taxpayer consciousness. It would be more appropriate to target students in secondary and tertiary institutions. The overall effort should involve both the education and finance ministries in order to come up with an effective tax education curriculum.

(iv) The monarchs (Obi, Oba and Emir) are very close to the people they rule over. The tax authorities should therefore maintain close relationship with the monarch and explore such relationship to bring more people into the tax net and also increase the level of taxpayer's compliance. Town hall meeting should be encouraged and through this, the general public can more fully understand taxation issues, changes in the law, filing obligations and so on.

(v) Tax officials should be exposed to adequate and continuous training; both at home and abroad, for a better understanding of recent domestic and international tax issues, which could then be utilized, to formulate successful tax compliance strategies. The working conditions of tax officials also need to be improved in order to motivate them to carry out their duties in a more efficient and professional manner.

\section{TEXTBOOKS}

\section{References And Bibliography}

[1]. Abdulrazaq, M.T. (1993). Principles and practice of Nigerian tax planning and management. Ilorin: Batay Publications Limited.

[2]. Aitken, S. \& Bonneville, L. (1980). A general taxpayer opinion survey. Washington D.C: Internal Revenue Service.

[3]. Asika, N. (2000). Research methodology in the behavioral sciences. Lagos: Longman Nigeria Plc.

[4]. Attwell, R.L. \& Sawyer, A. J. (2001). The ethical attitudes of New Zealand tax practitioners-still 'barely passing'? New Zealand Journal of Taxation Law and Policy, 7(2). Australian Taxation Office (1997). Australian Taxation Office annual report 19961997, Canberra: Commonwealth of Australia.

[5]. Ayres. F. L. \& Braithwaite, J. (1992). Responsive regulation: transcend the deregulation debate, New York, Oxford University Press.

[6]. Beck, P., Davis, J. \& Jung, W. (1994). Tax advice and reporting under uncertainty: theory and an experimental evidence. Illin ois: University of Illinois.

[7]. Braithwaite, V. \& Braithwaite, J. (2000). An evolving compliance model for tax enforcement. In N. Shover and J.P. Wright (Eds.) Crimes of privilege. New York: Oxford University Press.

[8]. Brehm, S. S. \& Brehm, J. W. (1981). Psychology Reactance: A theory of freedom and control, New York, Academic Press.

[9]. Frey, B.S. (2003). "The role of deterrence and tax morale in taxation in European countries"Netherlands Institute for Advance Studies in Humanities and Social Sciences, Wassenaar

[10]. Goel, M.L. (1988). A methods handbook: Political science research , Iowa: Iowa State University Press.

[11]. Haslam, S.A. (2001). "Psychology in organization: The social identity approach", London, Sage Publication.

[12]. Hatcher, L. (1994). A step-by-step approach to using the SAS(R) system for factor analysis and structural equation modeling. Cary, NC: SAS Institute.

[13]. Homes,G. C. (1961). Social behavior: Its elementary form, New York: Harcourt, Brace and World

[14]. James, S. \& Nobes, C. (1992). Taxation: Theory and practice. London, Prentice Hall.

[15]. Kagan, R. A. \& Scholz, J. T. (1984). The Criminology of the Corporation and Regulatory Enforcement Strategies, in: K. Hawkins and J.M. Thomas (eds.), Enforcing regulation . (Boston; Kluwer-Nijhoff Publishing.

[16]. Kelman, H.C. (1965). International behavior: A social psychological analysis, New York: Holt, Rinehart and Wiston

[17]. Kinsey, K. A. (1987). Theories and models of tax cheating, Chicago: American Bar Association.

[18]. Kirchler, E., Maciejovsky, B. \& Schneider, F. (2001). Mental accounting and the impact of tax penalty and audit frequency on the declaration of income: An experimental analysis, Humboldt: University of Berlin.

[19]. Lewis, H. B. (1971). Shame and guilt in neurosis, New York: International University Press.

[20]. Lewis, A. (1982). "The psychology of taxation", Oxford, Martin Robertson

[21]. Lind, E.A., \& Tyler, T. R. (1988). The social psychology of procedural justice, New York, Plenum Press.

[22]. McBarnet, D. (1992). The construction of compliance and the challenge for control: The limits of noncompliance research. Ann Arbor: University of Michigan Press: 333-348.

[23]. McBarnet, D. (2003). When Compliance is not the Solution but the Problem: from changes inlaw to changes in attitude, in: V. Braithwaite (ed), Taxing democracy: Understanding tax avoidance and evasion. Aldershot: Ashgate.

[24]. McCrae, J. and Reinhart, M. (2003). Non-filers: What we know, Note 1, Centre for Tax System

[25]. McGill, G. A. (1983). The CPA's role in income tax compliance: An empirical study of variability in recommending aggressive tax position. Texas: Texas Tech. University.

[26]. Musgrave, R.A. (1959). "The theory of public finance: A study of political economy. New York: Mcgraw-Hill.

[27]. Nightingale, K. (2001). Taxation: Theory and practice. London, Prentice HallOgbeide, U. (1997). Statistical techniques for social and management sciences. Lagos: Amfitop Books.

[28]. Ola, C.S. (1981). Income tax law for corporate and unincorporated bodies in Nigeria. Ibadan: Heineman Educational Books.

[29]. Otusanya, O.J. (2001). Taxation, Lagos, University of Lagos Press.

a. Roth, J. A. , John T. S. \& Witte A. D. (1989). Taxpayer compliance: Social science perspectives. Philadelphia: University of Pennsylvania Press.

[30]. Salkind, N.J. (2004). Statistics for people who (think they) hate Statistics (2nd edition) London: Sage Publications 
[31]. Sanders, M. , Lewis, P. \& Thomhill, A. (1997). Research methods for business students. London Financial Times-Pitman Publishing.

[32]. Seldon, A. (1979). "Tax avoision: The economic legal and moral inter-relationship between avoidance and evasion", Institute of Economic Affairs, London.

[33]. Spicer, M. W. (1974). A behavioral model of income tax evasion, Ohio: Ohio State University.

[34]. Tajfel, H.\& Turner, J. C.(1986). The social identity theory of inter group behaviour. In S.

[35]. Worchel and W.G. Austin (Eds.) Psychology of Inter-group Relations. U.S.A.: Nelson-Hall.

[36]. Turner, J. C. (1985). Social categorization and self concept: A social cognitive theory of group behaviour . In E.J. Lawler (Eds.) Advances in group processes. Vol.2. Greenwich, Conn: JAI Press.

[37]. Turner, J. C. \& Oakes, P. J. (1997). The socially structured mind. In C. McGarty and S. A.

[38]. Haslam (Eds.). The message of social psychology. Oxford: Blackwell Publishers.

[39]. Tyler, T. R. \& Degoey, P. (1996). Trust in organizational authorities: The influence of motive attributions on willingness to accept decisions. In R. Kramer and T. R. Tyler (Eds.). Trust in organization. thousand oaks, California: Sage

[40]. Tyler, T. R. (2001). Social Justice. In R. Brown and S. Gaertner (Eds.), Blackwell handbook of social psychology: Intergroup processes. Oxford: Blackwell Publishers Ltd.

[41]. Webber, C. \& Wildasky, A. (1986). A history of taxation and expenditure in the Western World. New York: Simon and Schuster.

[42]. Webley, P., Robben, H Elffers, H. \& Hessing, D. (1991).Tax evasion: An experimental approach. Cambridge: Cambridge University Press.

\section{Conference And Working Papers}

[43]. Blumenthal, M., Christian, C. \& Slemrod, J. (1998). The determinants of income tax compliance: Evidence from a controlled experiment in Minnesota, National Bureau of Economic Research Working Paper no 6575, Massachusetts.

[44]. Braithwaite, V., Reinhart M., Mearns, M. \& Graham, R. (2001). Preliminary findings from the community hopes, fears, and action survey. Center for Tax System Integrity Working Paper no 3. Canberra: The Australian National University.

[45]. James, S., Murphy, K. \& Reinhart, M. (2005). "Taxpayers belief and views: A new survey", Paper No.03/05, Australian National University, Canberra.

[46]. Murphy, K. \& Byng, K. (2002). Preliminary findings from the Australian tax system survey of tax scheme investors. Center for Tax System Integrity Working Paper no 40. Canberra: The Australian National University.

[47]. Odusola, A. (2006). "Tax policy reforms in Nigeria", World Institute for Development Economic Research, Research Paper No 2006/3, United Nations University.

[48]. Sakurai, Y. \& Braithwaite, V. (2001). Taxpayers' perceptions of the ideal tax adviser: playing save or saving dollars ?, Working Paper No 5: Australian National University.

[49]. Taylor, N. (2001). Understanding taxpayer attitudes through understanding taxpayer identities. Center for Tax System Integrity Working Paper no. 14 Canberra: The Australian National University.

[50]. Tooley, S. (1992). Tax practitioners: Towards an understanding of ethical problems and attitudes. Discussion paper. Palmerston North: Massy University, Accountancy Department.

[51]. Wenzel, M. (2002). "Principles of procedural fairness in reminder letters: A field experiment", Centre for Tax System Integrity, Working Paper No 42, Canberra: The Australian National University.

[52]. William, R. (2001). Prosecuting non-lodgers: To persuade or punish ?, Centre for Tax System Integrity Working Paper No. 12, Canberra: The Australian National University.

\section{Journals}

[53]. Allingham, M. G. \& Sandmo A. (1972). Income tax evasion: A theoretical analysis, Journal of Public Economic, 1:323-338.

[54]. Alm, J.,G., McClelland, H \& Schulze, W. D. (1992). Why do people pay tax ?. Journal of Public Economics. 48: 21-48.

[55]. Alm, J., B., Jackson, R. \& McKee, M. (1992). Estimating the determinants of taxpayer compliance with experimental data, National Tax Journal. 45: 107-115.

[56]. Alm, J. Sanchez, I. \& DeJuan, A. (1995). Economic and noneconomic factors in tax compliance, Kyklos,48: 3-18.

[57]. Alm, J., Mclelland, G. H. \& Schulze, W. D. (1999). "Changing the social norm of tax compliance by voting", Kyklos, 48: $141-171$.

[58]. Andreoni, J., Erard B. \& Feinstein, J. (1998). Tax compliance, Journal of Economic Literature. 36: 818-860.

[59]. Ayres, F.L., Jackson, B. R. \& Hite, P. (1989). The economic benefits of regulation: Evidence from professional tax prepares. The Accounting Review 64, 300-312.

[60]. Baldry, J. C. (1987). Income tax evasion and tax schedule: Some experimental results, Public Finance. 422: $357-383$.

[61]. Becker, G.S. (1968). Crime and punishment: An econometric approach, Journal of Political Economy. 76: $169-217$.

[62]. Braithwaite, V., J. Braithwaite, J., Gibson, D. \& Makkai, T. (1994). Regulatory styles, motivational postures and nursing home compliance. Law and Policy, 16, 363-394.

[63]. Bordignon, M. (1993). A fairness approach to income tax evasion. Journal of Public Economic. 52, 345-362

[64]. Chung, P. (1976). "On complaints about high taxes: An analytical note”. Public Finance, 31,

a. $\quad 36-47$.

[65]. Collins, J. H., V.C. Milliron. V.C. \& Toy, D. R. (1990). Factors associated with household demand for tax preparers. The Journal of American Taxation Association, 12, 9-15.

[66]. Cowell, F. A.. \& Gordon, J. P. F. (1988). Unwillingness to pay: Tax evasion and public goods provision, Journal of Public Economics. 36, 305-321.

[67]. Cowell, F. A. (1992). Tax evasion and inequity, Journal of Economic psychology. 13, 521-543.

[68]. Dubin, J. A., Graetz, M., Udell, A. \& Wilde, L. L. (1992). The demand for tax return preparation services. Review of Economic and Statistics. 74, 75-82.

[69]. Erard, B. (1993). Taxation with representation: An analysis of the role of the practitioners in tax compliance. Journal of Public Economics. 52, 163-197.

[70]. Erard, B. \& Feinstein, J. S. (1994). The role of moral sentiments and audit perceptions in tax compliance. Public Finance. 49, 7089.

[71]. Falkinger, J. (1995). Tax evasion, consumption of public goods and fairness. Journal of Economic Psychology.16, 63 -72.

[72]. Fehr, E. \& Rockenbach, B. (2003). Detrimental effect of sanctions on human. Attruism, Nature.422, 137-140.

[73]. Feld, L, P. \& Frey, B. S. (2002). Trust breed trust: How taxpayers are treated. Economics of Governance. 3, 87-99.

[74]. Frey, B. S. (1992). Pricing, regulating, and intrinsic motivation. Kyklos 45, 161-184.

[75]. Frey, B. S. \& Holler, M. J. (1998). Tax compliance policy reconsidered. Homo Oeconomicus. 15, 27-44. 
[76]. Grasmick, H. G. \& Bursik, R. J. (1990). Conscience, significant others, and rational choice: Extending the deterrence model. Law and Society Review. 24, 837-861.

[77]. Klepper, S., Mazur, M. \& Nagin, D. S. (1991). Expert intermediaries and legal compliance. the case of tax preparers. Journal of Law and Economics, 34, 205-229.

[78]. Krause, K. (2000). Tax complexity: Problem or opportunity. Public Finance Review. 28, 395-414

[79]. Lewis, A. (1979). An empirical assessment of tax mentality. Public Finance. 2, 245-257.

[80]. Long, J. E. \& Gwartney, J. D. (1987). Income tax avoidance: Evidence from individual tax return. National Tax Journal. 40, 51 7532 .

[81]. McGraw, K.. M. \& Scholz, J. T. (1991). Appeals to civic virtue versus attention to self-interest: Effect of tax compliance. Law and Society Review. 25, 471-498.

[82]. Moser, D.V., Evans, J. H. \& Kim, K. C. (1995). The effect of horizontal and exchange equity on tax reporting decisions. The Accounting Review. 70, 619-634.

[83]. Murphy, K. (2004). Aggressive tax planning: Differentiating those playing the game from those who don't. Journal of Economic Psychology. 25, 285-303.

[84]. Murphy, K. \& Harris, N. (2007). Shaming, shame and recidivism: A test of re integrative shaming theory in the white-coller crime context. British Journal of Criminology. 47, 900-917.

[85]. Murphy, K. (2008). Enforcing tax compliance: To punish or persuade?. Economic Analysis and Policy, 38, 113-135

[86]. Oates, W.E. (1995). Green Taxes, can we protect the environment and improve the tax system at the same time ?, Southern Economic Journal, 61, 915-922

[87]. Polinsky, M. A. \& Shavell, S. (2000). The economic theory of public enforcement of law. Journal of Economic Literature, 38, 4576.

[88]. Poterba, J. M. (1987). Tax evasion and capital gains taxation. American Economic Review, 77, 224-239.

[89]. Richardson, G. (2006). Determinant of tax evasion: A cross-country investigation. Journal of International Accounting, Auditing and Taxation, 15, 150-169

[90]. Schmidtchen, D. (1994). The prospect of taxpayer agreement with aggressive tax advice. Journal of Economic Psychology. 22, 157172 .

[91]. Slemrod, J. (1985). An empirical test for tax evasion. The Review of Economics and Statistics. 67, $232-248$

[92]. Smith, S. (1992). "Taxation and environment". Fiscal Studies, 15, 19-43.

[93]. Smith, H.J. \& Tyler, T. R. (1996). "Justice and power: When will justice concerns encourage the advantaged to support policies which redistribute economic resources and disadvantaged to willingly obey the Law". European Journal of Social Psychology, 26 , $171-200$.

[94]. Song, Y. \& Yarbrough, T. E. (1978). Tax ethics and taxpayers' attitudes: A survey. Public Administrative Review, 38, 442-452.

[95]. Spicer, M. W. \& Becker, L. A. (1980). Fiscal inequity and tax evasion: An experimental approach. National Tax Journal.

[96]. Spicer, M. W. (1986). Civilization at a discount: The problem of tax evasion. Journal of Public Economic, 46, 13-20.

[97]. Sugden, R. (1984). Reciprocity: The supply of public goods through voluntary contributions. Economic Journal, $94,772-787$.

[98]. Torgler, B. (2002). "Speaking to theorists and searching for facts: Tax morale and tax compliance in experiments". Journal of Economic Surveys, 16, 657-684.

[99]. Torgler, B. (2003). Theory and empirical analysis of tax compliance, Basel: University of Basel.

[100]. Tyler, T.R. \& Lind, A. (1992). "A relational model of authority in groups", Advances in Experimental Social Psychology, 22, 115 184.

[101]. Tyler, T. R. (1997). The psychology of legitimacy: A rational perspective on voluntary deference to authorities'. Personality and Social Psychology Review, 1(4), 323-345.

[102]. Tyler, T. R. (1997). Procedural fairness and compliance with the law. Swiss Journal of Economics and Statistics. 133, 219-240.

[103]. Viscusi, W. K. (1994). "Promoting smokers' welfare with reasonable taxation". National Tax Journal, 47, 547-558.

[104]. Vogel, J. (1974). Taxation and public opinion in Sweden: An interpretation of recent survey data. National Tax Journal. 27, 499513 .

[105]. Walker, I. \& Mann, L. (1987). Unemployment, relative deprivation and social protest. Personality and Social Psychology Bulletin, $13,275-283$

[106]. Wenzel, M. (2001). A social categorization approach to distributive justice: Social identity as the link between relevance of inputs and the need for justice. British Journal of Social Psychology, 40, 315-355.

[107]. Witte, A. D. \& Woodbury, D. F. (1985). The effect of tax laws and tax administration on tax compliance:The case of the U. S. individual income tax. National Tax Journal, 38, 1-15.

[108]. Yitzhaki, S. (1974). A note on income tax evasion: A theoretical analysis. Journal of Public Economics. 3, $201-212$.

\section{APPENDIX \\ QUESTIONNAIRE SCHEDULE \\ DEPARTMENT OF ACCOUNTING \\ DELTA STATE UNIVERSITY \\ ASABA CAMPUS}

Dear Respondent,

I am a researcher of the above named department and university. I wish to solicit your kind response to this questionnaire which is specially designed for the purpose of obtaining information on "analysis of tax morale and tax compliance in Nigeria". Therefore, the findings would be strictly for research purposes. I will be grateful if the questions in this questionnaire are answered correctly, as absolute confidentiality is assured.

Yours Sincerely,

Akan David Chucks

QUESTIONNAIRE 
Gender:

Marital Status:

(Male)

(Female)

Religion: (Circle as appropriate)

(Married) (Single) (Others)

(Christian) (Muslim) (Traditional)

Are you working (Circle as appropriate) 1 For Government/Public Organization

2 Private Business/Industry

3 Self Employed

Would you describe yourself as belonging to (Upper Class) (Middle Class)

(Lower Class)

Age Groups: (Tick as appropriate) $\quad(18-29)(30-39) \quad(40-49) \quad(50+)$

Education: What is your highest level of education? (Tick as appropriate)

(Primary) (Secondary) (Polytechnic) (University)

SECTION A

Please use this scale (Circle one number against each statement) for the following statement:

$\begin{array}{ccccc}\text { Strongly } & \text { Unacceptable } & \text { Slightly } & \text { Neither Acceptable } & \text { Slightly } \\ \text { Unacceptable } & \text { Unacceptable } & \text { Nor Unacceptable } & \text { Acceptable } & \\ 6 & & 7 & \end{array}$

Strongly Acceptable

1 Trading or exchanging goods or services with friends or neighbor and not reporting it in your tax form.

122345567

2 Reporting your main income fully, but not including Small outside income.

3 Being paid in cash for a job and then not reporting

it in your tax form.

122345567

4 Not reporting some earnings from investment or interest that the government would not be able to find out.

5 Cheating on Tax if you have the chance.

SECTION B

Now I will describe some people. Please use this scale (Circle one number against each statement) for the following statements:

$\begin{array}{clccc}1 & 2 & 3 & 4 & 5 \\ \text { Not at all } & \text { Not like } & \text { Somewhat } & \text { Neither like or } & \text { Somewhat } \\ \text { Like me } & \text { me } & \text { Unlike me } & \text { Unlike me } & \text { Like me } \\ 6 & & 7 & & \end{array}$

Like me Very much like me

1 He or She sees work as a duty towards society.

2 Adventure and taking risks are important to this person: to have an exciting life.

$3 \mathrm{He}$ or She behaves properly to avoid people saying anything wrong about Him or Her.
$\begin{array}{lllllll}1 & 2 & 3 & 4 & 5 & 6 & 7\end{array}$
$\begin{array}{lllllll}1 & 2 & 3 & 4 & 5 & 6 & 7\end{array}$
$\begin{array}{llllllll}1 & 2 & 3 & 4 & 5 & 6 & 7\end{array}$
$\begin{array}{lllllll}1 & 2 & 3 & 4 & 5 & 6 & 7\end{array}$
$\begin{array}{lllllll}1 & 2 & 3 & 4 & 5 & 6 & 7\end{array}$
$\begin{array}{lllllll}1 & 2 & 3 & 4 & 5 & 6 & 7\end{array}$
$\begin{array}{lllllll}1 & 2 & 3 & 4 & 5 & 6 & 7\end{array}$
$\begin{array}{lllllll}1 & 2 & 3 & 4 & 5 & 6 & 7\end{array}$ follow others

8 It is important to this person to be creative, to do things his own way.

SECTION C

Please tell me the justification of the following statements using this scale (Circle one number against each statement).

$\begin{array}{ccccc}1 & 2 & 3 & 4 & 5 \\ \text { Highly } & \text { Unjustifiable } & \text { Slightly } & \text { Neither justifiable } & \text { Slightly }\end{array}$


Unjustifiable 6 7

Unjustifiable nor Unjustifiable Justifiable

Justifiable

Highly Justifiable

1 Claiming government benefits to which you are not entitled.

2 Cheating on taxes if you have a chance.

3 Someone accepting a bribe in the course of their duties.

4 Avoiding a fare on Public transport.

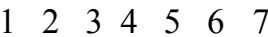

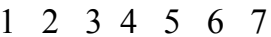

$\begin{array}{lllllll}1 & 2 & 3 & 4 & 5 & 6 & 7\end{array}$

$\begin{array}{lllllll}1 & 2 & 3 & 4 & 5 & 6 & 7\end{array}$

\title{
SECTION D
}

Please indicate (Circle one number against each) what your attitude are towards each of the following on the scale provided below:

\begin{tabular}{|c|c|c|c|c|}
\hline 1 & 2 & 3 & 4 & 5 \\
\hline Very & Unfavourable & Moderately & Neither Favourable & Moderately \\
\hline $\begin{array}{l}\text { Unfavourable } \\
\quad 6\end{array}$ & 7 & Unfavourable & Nor Unfavourable & Favourable \\
\hline
\end{tabular}

Favourable Very Favourable

1 Trust in Legal System

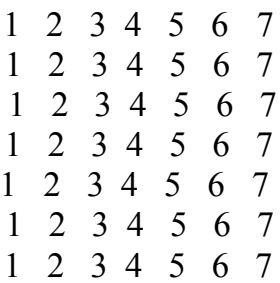

2 Trust in the Government at all levels

3 Trust in Tax Administration

4 Trust in Fairness of Tax Officials

5 Tax Evasion

6 Tax Avoidance

7 Tax Compliance

5

\section{Moderately Neither Favourable Moderately}

\author{
(1)
}


pollution but it should not cost me any money. $\begin{array}{lllllll}1 & 2 & 3 & 4 & 5 & 6 & 7\end{array}$

\section{SECTION G}

(A) Please kindly indicate 2 or 3 other issues regarding the Effect of Tax Morale on Tax Compliance in Nigeria

1

2

(B) Kindly suggest 2 or 3 ideas of resolving the issues of Tax Compliance in Nigeria.

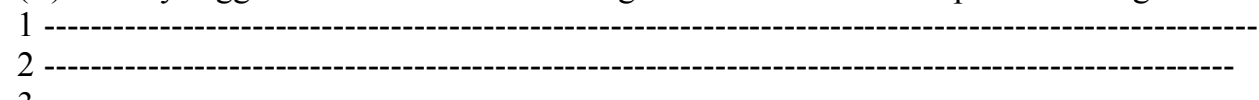

THANK YOU FOR HELPING ME. GOD BLESSES YOU. 